\title{
Effect of target spot on soybean yield and factors affecting this relationship
}

\author{
J. P. Edwards Molina ${ }^{a *}$ iD, P. A. Paul ${ }^{b}$, L. Amorim ${ }^{c}$, L. H. C. P. da Silva ${ }^{d}$, F. V. Siqueri ${ }^{e}$, \\ E. P. Borges ${ }^{f}$, H. D. Campos $^{g}$, W. S. Venancio ${ }^{h}$, M. C. Meyeri, M. C. Martins ${ }^{j}$, \\ R. S. Balardin ${ }^{k}$, V. J. Carlin', J. F. J. Grigollim , L. M. de R. Belufin ${ }^{\mathrm{n}}$, J. Nunes Junior ${ }^{\circ}$ and \\ C. V. Godoyi \\ aInstituto Nacional de Tecnología Agropecuaria, Instituto de Patología Vegetal - CIAP, 5020 Córdoba, Argentina; ' Department of Plant \\ Pathology, The Ohio State University, Ohio Agricultural Research and Development Center, Wooster, 44691, OH, USA; ' Departamento de \\ Fitopatologia e Nematologia, Universidade de São Paulo, Piracicaba, 13418-900, SP; ' Agro Carregal, Rio Verde, 75907-454, GO; ${ }^{\mathrm{e}}$ Fundação \\ Mato Grosso, Rondonópolis, 78750-000, MT; ${ }^{\dagger}$ Fundação Chapadão, Chapadão do Sul, 79560-00, MS; ' Universidade de Rio Verde, Rio \\ Verde, 75901-970, GO; ' Universidade Estadual de Ponta Grossa, Ponta Grossa, 84030-900, PR; 'Embrapa Soja, Londrina, 86001-970, PR; \\ ${ }^{j}$ Círculo Verde Assessoria Agronômica e Pesquisa, Luís Eduardo Magalhães, 47850-000, BA; ' Universidade Federal de Santa Maria, Santa

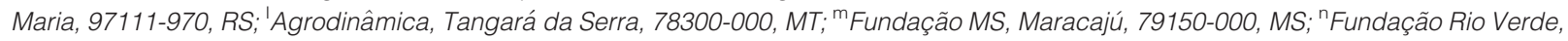 \\ Lucas do Rio Verde, 78455-000, MT; and ${ }^{\circ}$ Centro Tecnológico para Pesquisas Agropecuárias, Goiânia, 74130-012, GO, Brazil
}

The lack of robust estimates of soybean yield losses due to target spot led to this study. The objective was to determine whether soybean yield at stage $\mathrm{R} 8$ (W, expressed as $\mathrm{kg} \mathrm{ha}^{-1}$ ) was related to target spot severity at soybean stage R5-R6 ( $\mathrm{S}$, expressed as \%) and to identify variables that could affect this relationship. Plot-level estimates of mean disease severity and yield from 41 selected Uniform Fungicide Trials carried out in Brazil during 2012-2016 growing seasons were used to estimate linear regression coefficients for the relationship between yield and target spot severity through random-coefficient mixed effects model analysis. The overall estimated mean regression intercept and slope were $\widehat{\beta_{0}}=3564 \mathrm{~kg} \mathrm{ha}^{-1}$ (diseasefree yield) and $\widehat{\beta_{1}}=-17.1 \mathrm{~kg} \mathrm{ha}^{-1} \%^{-1}$ (W decrease per percent increase in S), respectively. The model was then refitted with different covariates to determine their effects on model parameters. $\beta_{0}$ was influenced by baseline yield (less than or greater than $3300 \mathrm{~kg} \mathrm{ha}^{-1}$ ) and $\beta_{1}$ was affected by yield response to fungicide treatments. Estimated yield loss at $50 \%$ target spot severity ranged from $8 \%$ to $42 \%$. Cultivar also had a significant effect on the magnitude of yield reduction due to target spot, which ranged from $11 \%$ to $42 \%$, depending on the cultivar.

Keywords: Corynespora cassiicola, cultivar tolerance, Glycine max, yield damage

\section{Introduction}

Target spot, caused by Corynespora cassiicola, is a common foliar disease of soybean in the tropics and subtropics (Dixon et al., 2009) that sometimes leads to premature defoliation (Sinclair, 1999). After first being reported in Brazil in 1976, it was considered a disease of limited importance for many years (Almeida et al., 1976). However, due to the widespread adoption of notill cultivation practices, sowing of susceptible cultivars and a reduction in the sensitivity of C. cassiicola to fungicides with single-site modes of action (Xavier et al., 2013), the disease has now spread to all major Brazilian soybean-growing regions (Godoy, 2015) and even to neighbouring Argentina, where it was the most prevalent disease during the 2014/2015 growing season (De Lisi \&

*E-mail: edwardsmolina.juan@inta.gob.ar

Published online 26 October 2018
Ploper, 2016). In the United States, target spot reemerged in the southeast in 2004-2005 probably as a consequence of changes in weather patterns and pathogen virulence, and/or the introduction of more susceptible soybean genotypes (Wrather \& Koenning, 2006).

Corynespora cassiicola survives on infected soybean debris and seed and may remain viable in fallowed fields for years (Almeida et al., 2001), serving as sources of primary inoculum for new epidemics. Typical foliar symptoms develop as reddish-brown, round to irregularly-shaped lesions, often surrounded by yellow halos ranging in diameter from 10 to $15 \mathrm{~mm}$. Lesions often develop concentric rings, giving them an appearance that has led to the common name of the disease: 'target spot'. Symptoms are observed first in lower strata of the canopy, later spreading up the plant (Almeida et al., 2005). Favourable conditions for target spot development commonly occur in Brazil from mid to late season, at the beginning of the reproductive stage of the crop when the canopy closes (Teramoto et al., 2013).

This early onset distinguishes target spot from late season diseases such as frogeye leaf spot (Cercospora 
sojina), brown spot (Septoria glycines) and cercospora leaf blight (Cercospora kikuchii), that are commonly first observed at or after grain fill (Carmona et al., 2015).

Reported effects of target spot on soybean yield vary among studies. For instance, Mesquini (2012) observed that target spot severity as high as $37 \%$ in the lower plant canopy did not cause yield reduction in a susceptible cultivar in Brazil. Contrastingly, however, based on results from a survey carried out in the southeastern USA in 2006, mean yield loss due to target spot was estimated at $20 \%$, with a maximum of $40 \%$ (Koenning et al., 2006). The lack of yield response to target spot in the former study may have been due to the relatively minor contribution of leaves in the lower canopy to seed formation and fill, when compared to leaves in the upper canopy that intercept more light (Sakamoto \& Shaw, 1967). However, further research is needed to test this hypothesis and to formally characterize and quantify relationships between target spot and soybean yield.

Most published studies on the impact of diseases on yield (or yield loss) in field crops are based on results from a single or small number of locations or years. Due to the narrow range of scenarios under which trials in such studies are performed, broad conclusions about the overall magnitude of treatment effects or strength of relationships among variables may be incorrect or misleading (Savary et al., 2006). Ideally, to quantify disease-yield relationships, similar experiments should be conducted in all geographical areas where the crop is important, over a period of at least 3 years, using widely cultivated cultivars under the range of conditions experienced in farmer's fields (James, 1974). In the case of target spot, recent increases in disease severity in Brazil (C. V. Godoy, unpublished observations) have led public and private research institutions to create a collaborative network of Uniform Fungicide Trials (UFTs) across several states to evaluate the efficiency of currently approved and experimental fungicides. A subset of the data from these UFTs was used in this investigation to: (i) quantify relationships between target spot severity and soybean yield, and (ii) identify variables that explain the heterogeneity in this relationship.

\section{Materials and methods}

\section{Uniform fungicide trials and study selection criteria}

A total of 56 target spot UFTs carried out across six Brazilian states (Bahia, Goiás, Mato Grosso, Mato Grosso do Sul, Paraná and Tocantins) during five growing seasons (2012-2016, years of harvest) were available to study the relationship between soybean yield and target spot severity. All cultivars used were classified as susceptible and, except for fungicide treatments and early sowing date (selected to escape from Asian soybean rust), all UFTs followed standard agronomic management practices as described by Godoy et al. (2012, 2013, 2014, 2015, 2016). Treatments consisted of three or four applications of registered or experimental fungicides, using $\mathrm{CO}_{2}$-pressurized sprayers, calibrated to deliver the product at a volume ranging from 150 to $200 \mathrm{~L} \mathrm{ha}^{-1}$.
The evaluated fungicides belonged to the following chemical groups: demethylation inhibitors (DMI: prothioconazole and epoxiconazole), quinone outside inhibitors (QoI: trifloxystrobin, pyraclostrobin and azoxystrobin), succinate dehydrogenase inhibitors (SDHI: fluxapiroxade, bixafen and benzovindiflupir), dithiocarbamate (mancozeb), methyl benzimidazole carbamates (MBC: carbendazim) and inorganic (copper oxychloride). Treatments were applied either as a stand-alone chemistry (carbendazim, mancozeb), a two-way mixture of a QoI and a DMI, or a QoI and an SDHI, or a three-way mixture of a QoI, a DMI and an SDHI.

Over the 5 years, four different combinations of six fungicides with different levels of efficacy against target spot plus a nontreated check were evaluated (Godoy et al., 2012, 2013, 2014, $2015,2016)$. This generated a range of plot-level mean severity and yield data for subsequent analyses. The first sprays were applied at 45-50 days after planting (before canopy closure) followed by repeat applications at 21-days intervals. Treatments were arranged in a randomized complete block with four or five replications. Each plot was at least six rows wide and $5 \mathrm{~m}$ long. A minimum of 12 leaves was examined at each of three heights within the crop canopy, and percentage leaf area exhibiting symptoms characteristic of target spot was assessed between the beginning seed (R5) and full seed (R6) growth stages (Fehr et al., 1971) with the aid of a diagrammatic scale (Soares et al., 2009). These soybean growth stages are considered highly sensitive to reductions in leaf area, with important impact on yield (Fehr et al., 1981). The two centre rows of each plot were harvested at full maturity, and yield was adjusted to $13 \%$ seed moisture content and expressed as $\mathrm{kg} \mathrm{ha}^{-1}$.

Only those trials in which the range of target spot severity (difference between the minimum and maximum plot-level mean severity) was higher than $10 \%$ and mean disease severity in the non-treated check was also greater than $10 \%$ were included in the analysis. An adequate range of disease severity and corresponding grain yield data is needed to quantify grain yield-disease severity relationships (Dalla Lana et al., 2015). Trials with soybean rust were also excluded $(n=3)$ to minimize the influence of other biotic stresses other than the effect of the target spot on yield. This resulted in 41 trials being retained for the analysis. Except for two trials (located in Paraná state, southern Brazil), all trials were located in the tropical savanna ecoregion of Brazil known as Brazilian Cerrado. This region has a semihumid tropical climate, with annual temperatures between 22 and $27^{\circ} \mathrm{C}$ and average rainfall of 800-2000 mm (Ratter et al., 1997).

\section{Data analysis}

Random-coefficient mixed model analysis

To estimate regression coefficients for the relationship between target spot severity and yield, a mixed effects model was fitted to the data from the 41 trials, allowing the intercepts and slopes to vary randomly among trials. This is called random-coefficient mixed model analysis (Madden \& Paul, 2009; Lehner et al., 2017). For the purpose of this analysis, plot-level mean severity and corresponding yield data from each of the 41 individual trials were used. The study-specific expectation of yield, i.e. the mean yield at a given disease level, for each individual study is given by:

$$
\begin{aligned}
& W_{i j}=\left(\beta_{0}+u_{0 i}\right)+\left(\beta_{1}+u_{1 i}\right) \mathrm{TS}_{i j}+e_{i j} \\
& u_{0 i} \sim N\left(0, \tau_{u_{0}}{ }^{2}\right) ; u_{1 i} \sim N\left(0, \tau_{u_{1}}{ }^{2}\right) ; e_{i j} \sim N\left(0, v^{2}{ }_{e}\right)
\end{aligned}
$$


where $W_{i j}, \mathrm{TS}_{i j}$, and $e_{i j}$ are soybean yield at the R8 growth stage, target spot severity at R5-R6, and residual, respectively, for the $j$ th observation (plot) within the $i$ th study. $\beta_{0}$ and $\beta_{1}$ are the population average intercept (expressed as $\mathrm{kg} \mathrm{ha}^{-1}$ ) and slope (expressed as $\mathrm{kg} \mathrm{ha}^{-1} \%^{-1}$ ), respectively, whereas $u_{0 i}$ and $u_{1 i}$ are the study-specific random effects of the $i$ th study on the intercept and the slope, respectively. The latter are considered normally distributed random variables with mean 0 and variances $\tau_{u_{0}}^{2}$ and $\tau_{u_{1}}^{2}$, respectively. The error term, $e_{i j}$, is also considered to be normally distributed with mean 0 and residual variance $v_{e}^{2}$. The sum of $\beta_{0}$ and $u_{0 i}$ or $\beta_{1}$ and $u_{1 i}$ gives the 'best linear unbiased prediction' (BLUP) for both parameters, respectively. The lmer function in the LME4 R package (Bates et al., 2015) was used to fit the data using the maximum likelihood method.

The random coefficient mixed model in Eqn 1 was expanded to account for the effects of different covariates on the target spot-yield relationship as:

$$
W_{i j k}=\left(\beta_{0}+\delta_{k}+u_{0 i}\right)+\left(\beta_{1}+\theta_{k}+u_{1 i}\right) \mathrm{TS}_{i j k}+e_{i j k}
$$

With the third subscript, $W_{i j k}$ and $\mathrm{TS}_{i j k}$ now represent yield and disease severity, respectively, for the $j$ th observation of the $i$ th study of the $k$ th level of the covariate; $\delta_{k}$ and $\theta_{k}$ represent the fixed effect of $k$ th level of the covariate on the intercept and slope, respectively. Six covariates that could potentially affect the relationship between target spot and yield were tested: (i) year of experiment (from 2012 to 2016); (ii) disease pressure as a factor variable (DP: Low $<35 \% \leq$ High) based on mean severity in the non-treated check (Edwards Molina et al., 2018); (iii) baseline yield as a categorical variable $\left(\mathrm{BY}_{\text {Low }} \leq\right.$ studies mean yield $=3300 \mathrm{~kg} \mathrm{ha}^{-1}<\mathrm{BY}_{\mathrm{High}}$ ) based on the mean yield of the most effective fungicide treatment (epoxiconazole + fluxapyroxad + pyraclostrobin) against target spot (Edwards Molina et al., 2018); (iv) mean yield response, based on $\%$ difference in yield between non-sprayed check and epoxiconazole + fluxapyroxad + pyraclostrobin fungicide treatment $\left(\right.$ YR, $\left[\left(\right.\right.$ yield $_{\text {Treated }}-$ yield $\left._{\text {Check }}\right) /$ yield Check $] \times 100$ : Low $\leq 10 \%$ $<$ High) (Scherm et al., 2009); (v) cultivar growth habit (determinate or indeterminate); (vi) soybean cultivar. To evaluate the effect of cultivar on the relationship between target spot and yield, the dataset was reduced to 23 studies, composed of the three cultivars most frequently used in the UFTs: BMX Potência RR $(n=8)$, M9144 RR $(n=8)$ and TMG8003 $(n=7)$. The random-coefficient mixed model was then refitted to the reduced dataset with cultivar as a categorical covariate (Eqn 2) to determine the cultivar effect and to estimate regression coefficients for the relationship between soybean yield and target spot severity for each selected cultivar. The Akaike information criterion (AIC) and the likelihood ratio test were used for model evaluation as described by Madden \& Paul (2009).

\section{Prediction and relative yield loss}

To allow for the comparison of study results with other published reports, yield response (and yield loss) was expressed on a relative scale. For that purpose, a damage coefficient (DC) was calculated by dividing the estimated slope $\left(\mathrm{kg} \mathrm{ha}^{-1} \%^{-1}\right)$ by the respective intercept $\left(\mathrm{kg} \mathrm{ha}^{-1}\right)$ and multiplying the quotient by 100 (Dalla Lana et al., 2015). The damage coefficient $\left(\%^{-1}\right)$ was then used to predict relative crop loss at any level of target spot severity as:

$$
L_{i}=\left(\frac{\beta_{1}}{\beta_{0}} 100\right) \mathrm{TS}_{i}
$$

where $L_{i}$ is the yield reduction (\%) for the $i$ th level of target spot severity $\left(\mathrm{TS}_{i}\right)$, and $\beta_{0}$ and $\beta_{1}$ are population average intercept and slope, respectively, estimated from the fit of the random-coefficient model (Eqns 1 or 2) to the data. For example, one can predict the potential yield loss at the maximum level of target spot severity commonly observed at the field $(50 \%), L_{50}$, using Eqn 3.

\section{Results}

\section{Variables description for primary studies}

Considerable variability was observed among the 41 selected studies in terms of target spot severity (means in the non-treated plots ranged from $11 \%$ to $52.6 \%$, with a median of $29.4 \%$; Fig. 1a) and soybean yield (means in the epoxiconazole + fluxapyroxad + pyraclostrobin treated plots ranging from 2134 to $4401 \mathrm{~kg} \mathrm{ha}^{-1}$, with a median value of $3537 \mathrm{~kg} \mathrm{ha}^{-1}$; Fig. 1b). Considering all plots (treated with fungicides varying in efficacy), median soybean target spot severity was $13.7 \%$ and median soybean yield was $3366 \mathrm{~kg} \mathrm{ha}^{-1}$ (Fig. 2). With the exception of three studies, there was a general trend towards a negative linear relationship between soybean yield and target spot severity (Fig. 2). The study-specific linear regression intercepts and slopes ranged from 2203 to $4850 \mathrm{~kg} \mathrm{ha}^{-1}$ and from -60.8 to $9.1 \mathrm{~kg} \mathrm{ha}^{-1} \%{ }^{-1}$, respectively.

\section{Population average regression coefficients}

A significant likelihood ratio test $(P<0.001)$ and AIC $=21804$ suggested that the model (Eqn 1) allowing the intercepts and slopes to (randomly) vary across studies was the best model to summarize the overall relationship between soybean yield and target spot severity. The estimated population-average regression intercept was $3564 \mathrm{~kg} \mathrm{ha}^{-1}$ and the slope was $-17 \mathrm{~kg} \mathrm{ha}^{-1} \%-1$ (Table 1; Fig. 3a). With the estimated regression coefficients, the damage coefficient was calculated as $0.48 \%^{-1}$ which, based on Eqn 3, would represent a yield loss of $12 \%$ at $25 \%\left(L_{25}\right)$ and $24 \%$ at $50 \%$ severity $\left(L_{50}\right)$. BLUP histograms showed a slight left-skewed distribution for the intercepts, with the highest accumulation from 3000 to $4000 \mathrm{~kg} \mathrm{ha}^{-1}$ (Fig. 3b), and a bimodal distribution of the slopes (Fig. 3c).

\section{Effects of covariates on the target spot-yield relationship}

Two of the five tested covariates had a significant effect on the relationship between target spot severity and soybean yield: baseline yield significantly affected the intercept $(P<0.001)$, whereas yield response affected the slope $(P<0.001)$. Therefore, based on results from the fit of Eqn 2, the overall model was split into four regression equations to account for the effects of these covariates (Table 1; Fig. 4). 

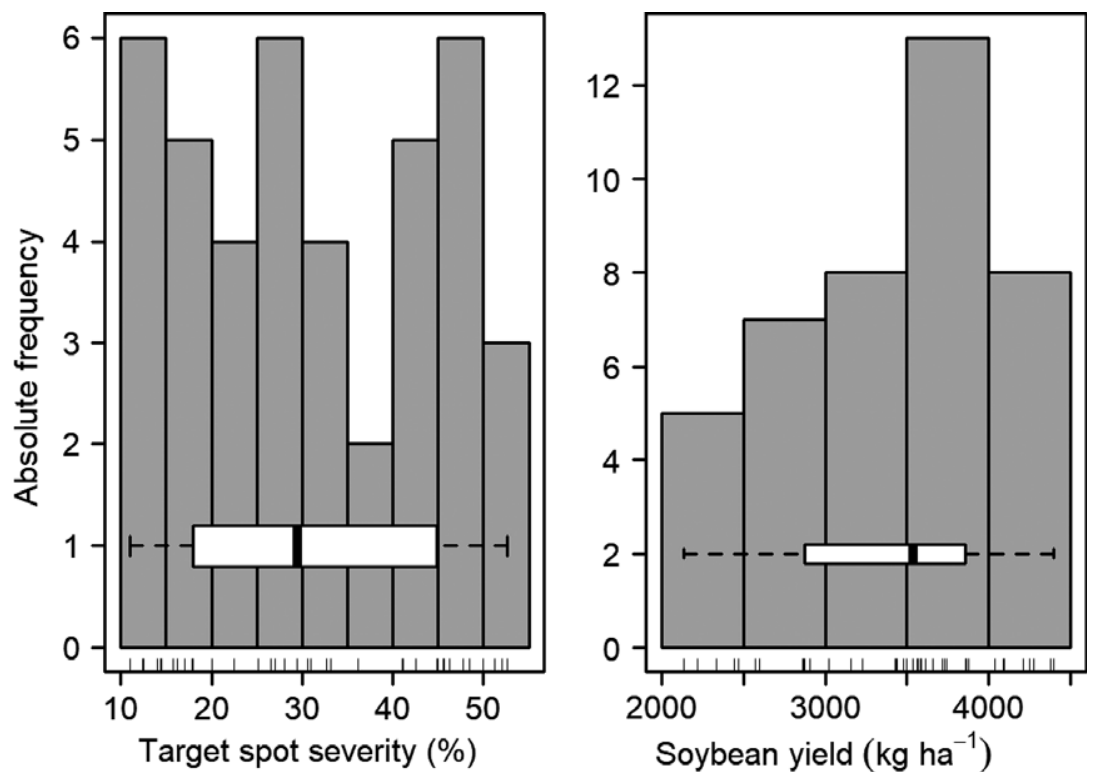

Figure 1 Histograms showing the distribution of observed mean target spot severity in non-treated check plots (a), and soybean yield for a reference fungicide treatment (epoxiconazole + fluxapyroxad + pyraclostrobin) (b), across 41 selected Uniform Fungicide Trials performed in Brazil from the 2012 to 2016 growing seasons. Horizontal white boxplots indicate interquartile range (IQR) and thick black lines within the boxplots are the median values.

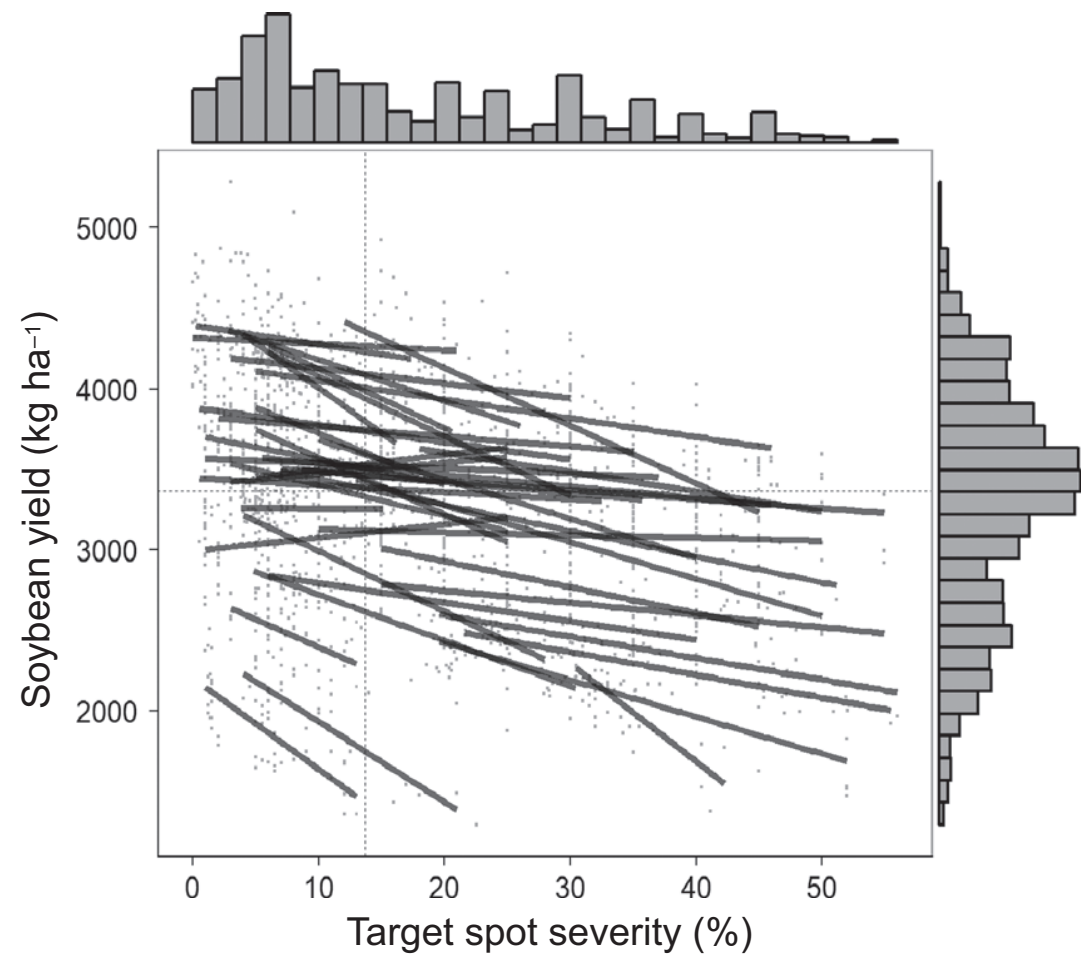

Figure 2 Regression lines for relationships between soybean yield and target spot severity for 41 Uniform Fungicide Trials performed in Brazil from the 2012 to 2016 growing seasons. Histograms at the top and right show the distributions of target spot severity (horizontal) and soybean yield (vertical), respectively. Dotted lines extending from the histograms to the $x$ - and $y$-axes represent median target spot severity and soybean yield, respectively. 
Table 1 Linear regression coefficients for the overall model and the full model for the relationship between soybean yield and target spot severity, including significant moderator variables.

\begin{tabular}{|c|c|c|c|c|}
\hline Coefficient & Estimate $^{a}$ & SE & $\mathrm{Cl}_{\text {Low }}$ & $\mathrm{Cl}_{\mathrm{High}}$ \\
\hline \multicolumn{5}{|l|}{ Overall model } \\
\hline Intercept & 3564 & 99.36 & 3376 & 3753 \\
\hline Slope & -17.1 & 2.27 & -21.4 & -12.5 \\
\hline \multicolumn{5}{|l|}{ Full model } \\
\hline \multicolumn{5}{|l|}{ BY $_{\text {Low }}{ }^{a}$} \\
\hline Intercept & 2932 & 99.1 & 2737 & 3125 \\
\hline \multicolumn{5}{|l|}{ BY High } \\
\hline Intercept & 3916 & 143.3 & 3770 & 4063 \\
\hline \multicolumn{5}{|l|}{$\mathrm{YR}_{\text {Low }}{ }^{\mathrm{b}}$} \\
\hline Slope & -6.34 & 2.73 & -11.1 & -1.6 \\
\hline \multicolumn{5}{|l|}{$\mathrm{YR}_{\text {High }}$} \\
\hline Slope & -23.7 & 2.55 & -27.9 & -19.3 \\
\hline
\end{tabular}

${ }^{\mathrm{a}} \mathrm{BY}$, baseline yield, based on the yield of the reference fungicide treatment (Low $<3300 \mathrm{~kg} \mathrm{ha}^{-1} \leq$ High).

${ }^{b} Y R$, yield response, based on the \% increment of the reference fungicide relative to the non-treated check (Low $<10 \% \leq$ High).

$$
\begin{aligned}
& \text { Yield }\left(\mathrm{BY}_{\text {Low }} \mathrm{YR}_{\text {Low }}\right) \\
& =2932 \mathrm{~kg} \mathrm{ha}^{-1}-6.3 \mathrm{~kg} \mathrm{ha}^{-1} \%^{-1} \cdot \mathrm{TS} \\
& \text { Yield }\left(\mathrm{BY}_{\text {Low }} \mathrm{YR}_{\text {High }}\right) \\
& =2932 \mathrm{~kg} \mathrm{ha}^{-1}-23.7 \mathrm{~kg} \mathrm{ha}^{-1} \%^{-1} \cdot \mathrm{TS} \\
& \text { Yield }\left(\mathrm{BY}_{\mathrm{High}} \mathrm{YR}_{\text {Low }}\right) \\
& =3916 \mathrm{~kg} \mathrm{ha}^{-1}-6.3 \mathrm{~kg} \mathrm{ha}^{-1} \%^{-1} \cdot \mathrm{TS} \\
& \text { Yield }\left(\mathrm{BY}_{\mathrm{High}} \mathrm{YR}_{\mathrm{High}}\right) \\
& =3916 \mathrm{~kg} \mathrm{ha}^{-1}-23.7 \mathrm{~kg} \mathrm{ha}^{-1} \%-1
\end{aligned}
$$

The damage coefficients (DC) for each combination are presented in Figure 4. The highest DC value, $0.81 \%^{-1}$, was estimated for the combination of $\mathrm{BY}_{\text {Low }}+\mathrm{YR}_{\mathrm{High}}$, which corresponded to an estimated $L_{50}$ of $40.5 \%$; followed by the $\mathrm{BY}_{\mathrm{High}}+\mathrm{YR}_{\mathrm{High}}$ combination, with a DC of $0.6 \%^{-1}$ and a $L_{50}$ of $30 \%$; the $\mathrm{BY}_{\text {Low }}+\mathrm{YR}_{\text {Low }}$ combination with a DC of $0.22 \%^{-1}$ and $L_{50}$ of $11 \%$; and finally the combination of $\mathrm{BY}_{\text {High }}+\mathrm{YR}_{\text {Low }}$, with a DC of $0.16 \%^{-1}$ and $L_{50}$ of $8 \%$.

For the reduced dataset, it was evaluated whether cultivars BMX Potência RR, M9144 RR or TMG803 were equally distributed across the combination of the covariates BY and YR. Cultivar BMX Potência RR was predominant in studies with $\mathrm{BY}_{\text {Low }}+\mathrm{YR}_{\text {Low }}$ (5 of 8 studies); cultivar M9144 RR was predominant in $\mathrm{BY}_{\text {Low }}+\mathrm{YR}_{\text {High }}$ (7 of 8 studies); whereas TMG803 was more equally distributed across the four combinations of the two covariates (Figs $5 \&$ S1). Cultivar had a significant effect on both the intercept $(P=0.003)$ and slope $(P=0.03)$ of the target spot-yield relationship. The estimated coefficients are presented in Table 2 and the damage coefficients in Table 2 and Figure 5. There was considerable variability in yield loss among the cultivars, with BMX Potência RR being the most tolerant cultivar $\left(L_{50}=10 \%\right)$; M9144 RR the least tolerant $\left(L_{50}=41 \%\right)$ and TMG803 intermediate $\left(L_{50}=18.5 \%\right)$.

\section{Discussion}

Target spot has the potential to cause significant yield loss in a soybean crop. However, the magnitude of this effect is known to be inconsistent, with reports of no loss in some studies (Faske \& Kirkpatrick, 2011; Ploper et al., 2013) to as much as $40 \%$ yield reduction in other cases (Koenning et al., 2006). This study observed potential yield losses of soybean due to target spot which were similar to the reported range, i.e. from $8 \%$ to $40.5 \%$. However, findings from the current study will help to explain the specific conditions under which low or high yield losses due to target spot may occur.

As suggested by James (1974), in order to incorporate effects of a wide range of growing conditions, data was taken from 41 UFTs collected over five growing seasons across the main Brazilian soybean production region. To the authors' knowledge, this is the first study to estimate and model the damage caused by target spot on soybean yield across multiple locations and years. A damage coefficient was observed of $0.48 \%^{-1}\left(\mathrm{~kg} \mathrm{ha}^{-1}\right.$ of soybean per percentage increment of target spot severity, based on a disease-free yield of $3564 \mathrm{~kg} \mathrm{ha}^{-1}$ ), which corresponds to a potential yield loss of $24 \%$ at $50 \%$ target spot severity. This yield loss level is within the range of values previously reported for this disease (Koenning et al., 2006). The most efficient fungicides to control target spot in the main Brazilian soybean-growing region were the mixture of fluxapyroxad + pyraclostrobin (from SDHI and QoI chemical groups, respectively) and this same mixture with the addition of the DMI fungicide epoxiconazole (Edwards Molina et al., 2018). These mixtures provided up to $75 \%$ disease control, with a 19 $20 \%$ yield increase over non-treated plots when disease severity was greater than $35 \%$.

The overall findings from this study should be interpreted with caution, as the damage caused by target spot depends on the specific environmental and agronomic conditions (Sinclair, 1999). For instance, in this study, the best target spot-yield models were those in which parameters for the effects of baseline yield and yield response on the coefficients were included. With these models, a wide range of potential losses, from $8-11 \%$ to $30-40.5 \%$, was observed. Then, two distinct scenarios can be considered: one in which there is little or no damage caused by target spot and another with highly significant losses due to target spot. For the first scenario, fungicide applications may not be profitable. However, for the second, fungicides would be strongly recommended to protect against target spot. Baseline yield, also considered by Faske \& Kirkpatrick (2011), was significant in the models, suggesting that the use of highyielding soybean cultivars under suitable edaphoclimatic 

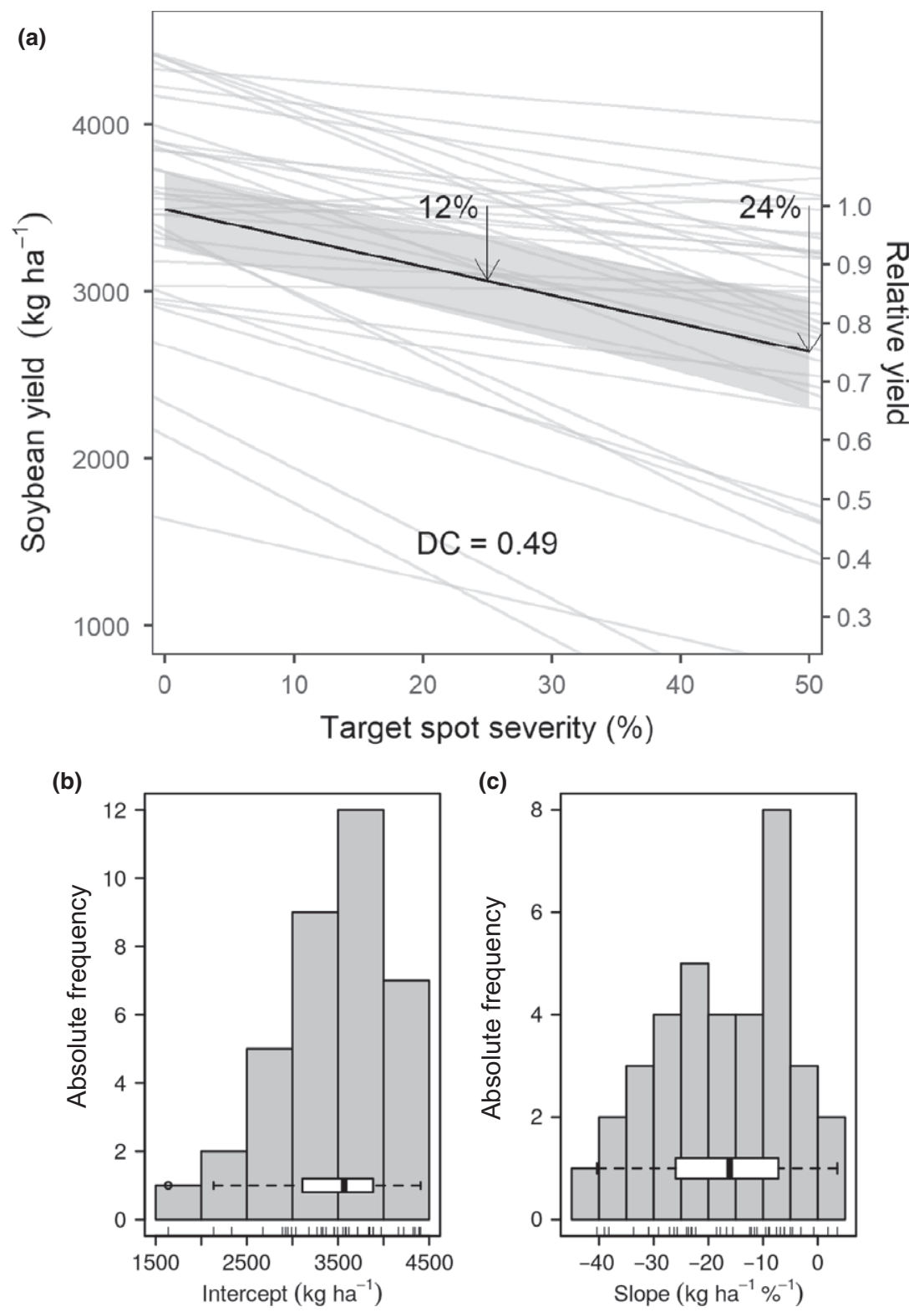
Figure 3 (a) Overall fitted linear regression line and $95 \%$ confidence interval (black solid and grey shaded area) and study-specific lines (grey lines) for relationships between soybean yield and target spot severity for 41 fungicide studies performed in Brazil from the 2012 to 2016 growing seasons; and histograms showing (b) the distribution of linear regression intercepts and (c) slopes across the 41 studies.

conditions may be a useful practice for minimizing yield losses due to target spot.

In this study, variability in the relationship between target spot and soybean yield was attributed primarily to two factors, baseline yield and yield response (i.e. yield response to an effective reference fungicide treatment). Several environmental factors could affect yield response to fungicide treatments, and as a result, influence the relationship between disease and yield. One such factor would be moisture availability during critical stages of crop growth such as between R3 and R5 (critical for grain development). For instance, above-normal seasonal rainfall is known to be beneficial for both crop growth and disease development, which, as a consequence, may lead to differences in yield response between fungicideprotected and unprotected plots.
Agronomic practices may also affect yield response to fungicides, and consequently, the relationship between target spot severity and yield, including row spacing, plant population, and tillage practices (among others). This may be due in part to direct or indirect effects of these practices on crop growth and disease development. For instance, Copper (1989) reported that yield response to benomyl treatment (fungicide not available on the market at present) for septoria brown spot control in soybean tended to be greater in a $17 \mathrm{~cm}$ row width than in a $75 \mathrm{~cm}$ row width. Treating plots with pyraclostrobin for frogeye leaf spot control led to yield gains ranging from $1 \%$ to $17 \%$ in soybean fields that were tilled but no yield gain was observed in no-till fields (Mengistu et al., 2014). The heterogeneity of yield response to fungicide in these two cases 
Figure 4 Prediction lines and 95\% confidence interval (grey-dashed area) for the fitted linear regression models for relationships between target spot and soybean yield, including the covariates baseline yield (BY; Low $\leq 3300 \mathrm{~kg} \mathrm{ha}^{-1}$ $<$ High) and yield response (YR; Low $\leq 10 \%$ yield increase with the reference fungicide $<$ High), solid or dashed lines respectively. Damage coefficients $(D C=$ slopeintercept $\times 100)$ for each combination of factors are shown within each plot.

Figure 5 Fitted regression lines for relationships between target spot and soybean yield for cultivars BMX Potência RR, M9144 RR and TMG803 (black lines, and 95\% confidence interval in grey shaded area) and observed study-specific models (grey lines). Damage coefficient (DC = slope/ intercept $\times 100$ ) for each cultivar represents the yield damage in $\mathrm{kg} \mathrm{ha}^{-1}$ for each \% increment in target spot severity.
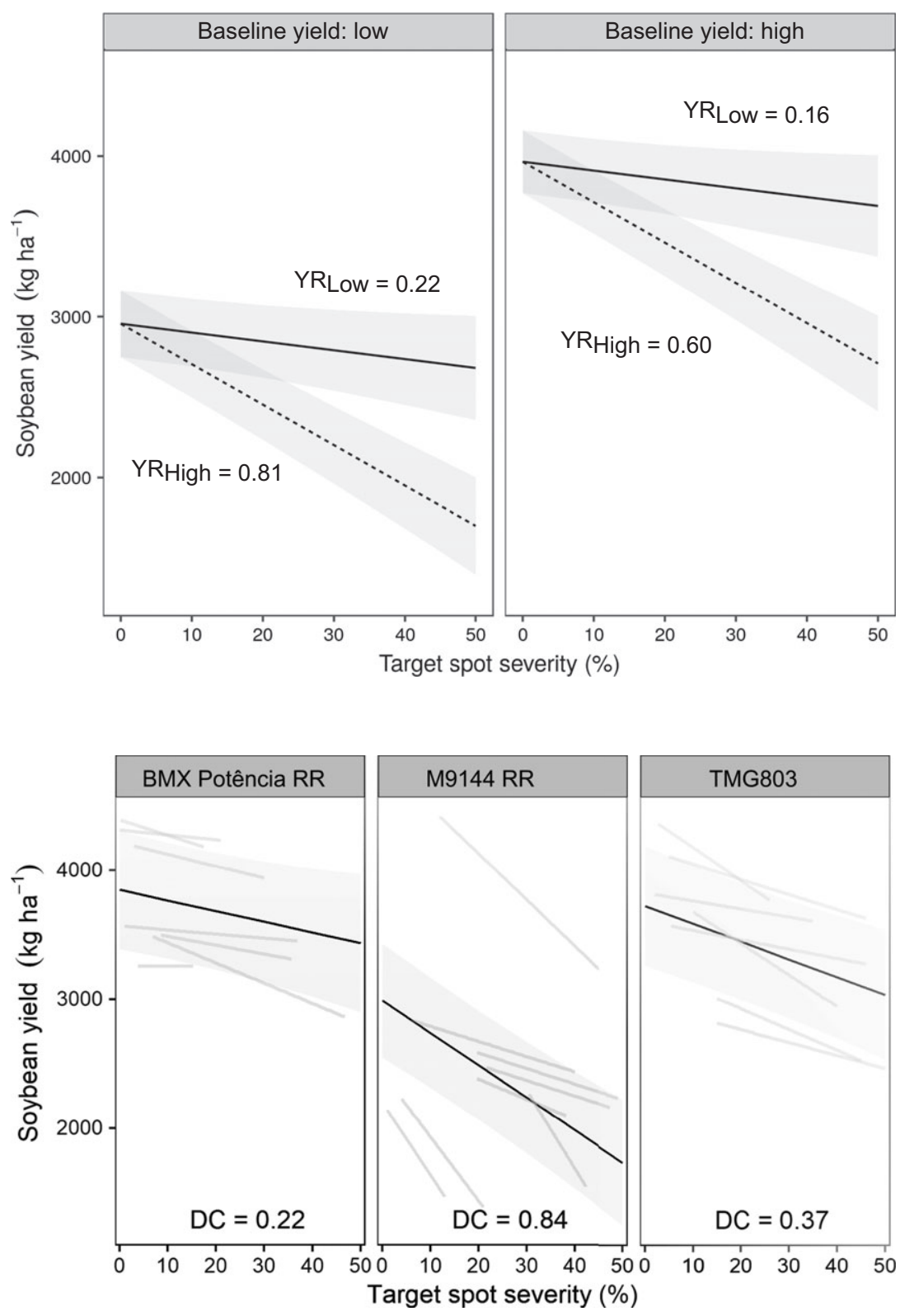

Table 2 Predicted intercepts $\left(\widehat{\beta_{0}}\right)$ and slopes $\left(\widehat{\beta_{1}}\right)$ for the selected soybean cultivars and their statistics.

\begin{tabular}{lllllll}
\hline \multirow{2}{*}{ Cultivar } & \multicolumn{7}{l}{ Regression coefficient } \\
\cline { 2 - 7 }$\widehat{\widehat{\beta_{0}}}$ & SE $^{a}$ & $\widehat{\beta_{1}}$ & SE & DC $^{\text {b }}$ & $L_{50}(\%)^{c}$ \\
\hline BMX Potência RR & 3850 & 233.9 & -8.31 & 3.96 & 0.22 & 11.0 \\
M9144 RR & 2992 & 324.0 & -25.1 & 5.43 & 0.84 & 42.0 \\
TMG803 & 3726 & 332.4 & -13.7 & 5.27 & 0.37 & 18.5 \\
\hline
\end{tabular}

aSE, standard error of the estimated $\beta$ coefficient.

${ }^{b} \mathrm{DC}$, damage coefficient calculated by dividing the estimated slope ( $\mathrm{kg} \mathrm{ha}^{-1} \%^{-1}$ ) by the estimated intercept $\left(\mathrm{kg} \mathrm{ha}^{-1}\right)$ and multiplying the quotient by 100 .

${ }^{c} L_{50}$, percentage yield reduction at hypothetical $50 \%$ target spot severity. were clearly linked to differences in cropping practices. However, based on the fact that very similar protocols were used in the UFT evaluated in the present study, differences in crop management practices are probably not a good explanation for the observed effect of yield response on the relationship between target spot and soybean yield.

Zadoks \& Schein (1979) defined 'tolerance' as plant internal factors that allow some cultivars to suffer less damage than others at the same level of injury. When comparing crop loss results among cultivars, $\beta_{1}$ from linear regression analysis of the relationship between disease and yield (loss) could be used as a measure of the tolerance of a cultivar to a given disease (Madden et al., 2007). It was observed that for cultivar BMX Potência 
$\mathrm{RR}$, there was a weak relationship between yield and disease severity, as made evident by a relatively small damage coefficient when compared to other cultivars. A small damage coefficient, as defined in this study, reflects a low rate of reduction in yield per percentage increase in disease severity (the slope) relative to the estimated yield in the absence of disease (the intercept). For BMX Potência RR, at the maximum level of target spot commonly observed in soybean fields $(50 \%)$, yield loss was only $11 \%$. At the other extreme, grain yield in cultivar M9144 RR was dramatically affected by target spot, with a yield loss of $42 \%$ at $50 \%$ target spot severity. These results corroborate the maximum reported yield losses due to this disease (Koenning et al., 2006), and are probably a reflection of differences in tolerance among the cultivars. However, further studies should be done to explore which compensation mechanisms allow BMX Potência RR to maintain fairly stable yields across increasing levels of target spot severity.

Cultivar growth habit (determinate or indeterminate) did not affect the regression coefficients nor the correlation between target spot severity and soybean yield (data not shown). Similar results were obtained by Copper (1989), suggesting that yield reductions due to septoria brown spot (and target spot in this case) vary with genotype, but were not specifically associated with growth habits.

Damage coefficients of $0.6-0.73 \%^{-1}$ were estimated for soybean rust and $0.49 \%^{-1}$ for white mould (Dalla Lana et al., 2015; Lehner et al., 2017). Based on the overall damage coefficients of $0.48 \%^{-1}$, target spot could be classified as a disease of intermediate importance. Using a reference baseline soybean yield of $3500 \mathrm{~kg} \mathrm{ha}^{-1}$, yield reductions of 168,172 and $212 \mathrm{~kg} \mathrm{ha}^{-1}$ would be expected for each $10 \%$ increment of target spot severity, white mould incidence and Asian rust severity, respectively. However, if a target spot tolerant cultivar such as BMX Potência RR were planted, the corresponding yield reduction would be predicted to be $77 \mathrm{~kg} \mathrm{ha}^{-1}$, compared to $294 \mathrm{~kg} \mathrm{ha}^{-1}$ if a less tolerant cultivar such as M9144 RR is used.

The wide variability of C. cassiicola populations (Dixon et al., 2009), continuous cultivation of susceptible varieties in no-till systems, and the use of ineffective fungicides such as carbendazim for disease control (Xavier et al., 2013), provide favourable conditions for continuous multiplication of C. cassiicola accompanied by selection for more aggressive strains in different soybean production environments. Based on the present findings, cultivar selection will be a key component of integrated management programmes for target spot. Further studies should be performed with several cultivars under the same or similar environmental conditions to assess resistance and tolerance. The environmental component remains a clear research priority for understanding how target spot epidemics can result in yield damage. This information is needed to gain a better insight for growers using fungicides as a profitable tool in sustainable agrosystems.

\section{Acknowledgements}

The authors thank the National Council for Scientific and Technological Development (CNPq) of Brazil for providing a scholarship to J.P.E.M., and to the network of researchers and technicians from several Brazilian institutes who contributed to obtain the field data for conducting this study.

\section{References}

Almeida AMR, Machado CC, Ferreira LP, Lehman PS, Antonio H, 1976. Ocorrência de Corynespora cassiicola (Berk. \& Curt.) Wei no estado de São Paulo. Fitopatologia Brasileira 1, 111-2.

Almeida AMR, Saraiva OF, Farias JRB, Gaudêncio CA, Torres E, 2001. Survival of pathogens on soybean debris under no-tillage and conventional tillage systems. Pesquisa Agropecuaria Brasileira 36, $1231-8$.

Almeida AMR, Ferreira LP, Yorinori J et al., 2005. Doenças da soja. In: Kimati H, Amorim L, Rezende JAM, Bergamin Filho A, Camargo LEA, eds. Manual de Fitopatologia, Vol. II. Piracicaba, Brazil: Editora Ceres, 569-88.

Bates D, Maechler M, Bolker B, Walker S, 2015. The LME4 package. Journal of Statistical Software 67, 1-48.

Carmona M, Sautua F, Perelman S, Gally M, Reis EM, 2015. Development and validation of a fungicide scoring system for management of late season soybean diseases in Argentina. Crop Protection 70, 83-91.

Copper RL, 1989. Soybean yield response to benomyl fungicide application under maximum yield conditions. Agronomy Journal 81, 847-9.

Dalla Lana F, Ziegelmann PK, Maia ADHN, Godoy CV, Del Ponte EM, 2015. Meta-analysis of the relationship between crop yield and soybean rust severity. Phytopathology 105, 307-15.

De Lisi V, Ploper LD, 2016. Enfermedades en el cultivo de la soja y su manejo. Campaña 2015/2016. [http://www.eeaoc.org.ar/upload/conte nido/pdf/20160712125604000000.pdf]. Accessed 10 May 2017.

Dixon LJ, Schlub RL, Pernezny K, Datnoff LE, 2009. Host specialization and phylogenetic diversity of Corynespora cassiicola. Phytopathology 99, 1015-27.

Edwards Molina JP, Paul PA, Amorim L et al., 2018. Meta-analysis of fungicide efficacy on soybean target spot and cost-benefit assessment. Plant Pathology. https://doi.org/10.1111/ppa.12925.

Faske T, Kirkpatrick T, 2011. Target spot of soybean. [https://www.uae x.edu/farm-ranch/crops-commercial-horticulture/docs/Faske $\% 2011 \%$ 20Target\%20spot\%20Soy.pdf]. Accessed 15 June 2017.

Fehr WR, Caviness CE, Burmood D, Pennington J, 1971. Stage of development descriptions for soybeans Glycine max (L.) Merrill. Crop Science 11, 929-31.

Fehr WR, Lawrence BK, Thompson TA, 1981. Critical stages of development for defoliation of soybean. Crop Science 21, 259.

Godoy CV, 2015. Target spot. In: Hartman GL, Rupe JC, Sikora EF, Domier LL, Davis JA, Steffey KL, eds. Compendium of Soybean Diseases and Pests. St Paul, MN, USA: APS Press, 62.

Godoy CV, Utiamada CM, Meyer MC et al., 2012. Eficiência de fungicidas para o controle da mancha-alvo, Corynespora cassiicola, na safra 2011/12: resultados sumarizados dos ensaios cooperativos. Embrapa Soja-Circular Técnica (INFOTECA-E). [https://ainfo.cnptia.e mbrapa.br/digital/bitstream/item/69328/1/CT94.pdf]. Accessed 6 September 2018.

Godoy CV, Utiamada CM, Meyer MC et al., 2013. Eficiência de fungicidas para o controle da mancha-alvo, Corynespora cassiicola, na safra 2012/13: resultados sumarizados dos ensaios cooperativos. Embrapa Soja-Circular Técnica (INFOTECA-E). [http://ainfo.cnptia.e mbrapa.br/digital/bitstream/item/90450/1/CT100.pdf]. Accessed 5 September 2018. 
Godoy CV, Utiamada CM, Meyer MC et al., 2014. Eficiência de fungicidas para o controle da mancha-alvo, Corynespora cassiicola, na safra 2013/14: resultados sumarizados dos ensaios cooperativos. Embrapa Soja-Circular Técnica (INFOTECA-E). [http://ainfo.cnptia.e mbrapa.br/digital/bitstream/item/107814/1/CT104.pdf]. Accessed 5 September 2018.

Godoy CV, Utiamada CM, Meyer MC et al., 2015. Eficiência de fungicidas para o controle da mancha-alvo, Corynespora cassiicola, na safra 2014/15: resultados sumarizados dos ensaios cooperativos. Embrapa Soja-Circular Técnica (INFOTECA-E). [http://ainfo.cnptia.e mbrapa.br/digital/bitstream/item/128834/1/CT112-1.pdf]. Accessed 5 September 2018.

Godoy CV, Utiamada CM, Meyer MC et al., 2016. Eficiência de fungicidas para o controle da mancha-alvo, Corynespora cassiicola, na safra 2015/16: resultados sumarizados dos ensaios cooperativos. Embrapa Soja-Circular Técnica (INFOTECA-E). [https://ainfo.cnptia.e mbrapa.br/digital/bitstream/item/146623/1/CT120-ManchaAlvo-OL. pdf]. Accessed 6 September 2018.

James WC, 1974. Assessments of plant disease and losses. Annual Review of Phytopathology 12, 27-48.

Koenning SR, Creswell TC, Dunphy EJ, Sikora EJ, Mueller JD, 2006. Increased occurrence of target spot of soybean caused by Corynespora cassiicola in the southeastern United States. Plant Disease 90, 974.

Lehner MS, Pethybridge SJ, Meyer MC, Del Ponte EM, 2017. Metaanalytic modelling of the incidence-yield and incidence-sclerotial production relationships in soybean white mould epidemics. Plant Pathology 66, 460-8.

Madden LV, Paul PA, 2009. Assessing heterogeneity in the relationship between wheat yield and Fusarium head blight intensity using randomcoefficient mixed models. Phytopathology 99, 850-60.

Madden LV, Hughes G, van den Bosch F, 2007. The Study of Plant Disease Epidemics. St Paul, MN, USA: APS Press.

Mengistu A, Kelly HM, Bellaloui N, Arelli PR, Reddy KN, Wrather AJ, 2014. Tillage, fungicide, and cultivar effects on frogeye leaf spot severity and yield in soybean. Plant Disease 98, 1476-84.

Mesquini R, 2012. Componentes Monocíclicos e Quantificação de Danos no Patossistema C. cassiicola. Piracicaba, Brazil: University of São Paulo, MSc thesis.

Ploper LD, González V, De Lisi V, Reznikov S, Henriquez DD, Devani MR, 2013. Research on target spot of soybean in northwestern
Argentina. In: Proceedings of the World Soybean Research Conference IX (WSRC IX). Durban, South Africa. [https://www.proteinresearch.ne t/imgs/wsrc2013/20-February-session-2/409_ploper-ld.pdf]. Accessed 5 September 2018.

Ratter J, Ribeiro JF, Bridgewater S, 1997. The Brazilian Cerrado vegetation and threats to its biodiversity. Annals of Botany 80, 223-30.

Sakamoto CM, Shaw RH, 1967. Light distribution in field soybean canopies. Agronomy Journal 59, 7-9.

Savary S, Teng PS, Willocquet L, Nutter FW, 2006. Quantification and modeling of crop losses: a review of purposes. Annual Review of Phytopathology 44, 89-112.

Scherm H, Christiano RSC, Esker PD, Del Ponte EM, Godoy CV, 2009. Quantitative review of fungicide efficacy trials for managing soybean rust in Brazil. Crop Protection 28, 774-82.

Sinclair JB, 1999. Target spot. In: Hartman G, Sinclair J, Rupe J, eds. Compendium of Soybean Diseases. St Paul, MN, USA: APS, 27.

Soares RM, Godoy CV, de Oliveira MCN, 2009. Escala diagramática para avaliação da severidade da mancha alvo da soja. Tropical Plant Pathology 34, 333-8.

Teramoto A, Machado TA, Volf MR, 2013. Reação de cultivares de soja à Corynespora cassiicola. Tropical Plant Pathology 38, 68-71.

Wrather JA, Koenning SR, 2006. Estimates of disease effects on soybean yields in the United States 2003 to 2005. Journal of Nematology 38, 173-80.

Xavier SA, Canteri MG, Barros DCM, Godoy CV, 2013. Sensitivity of Corynespora cassiicola from soybean to carbendazim and prothioconazole. Tropical Plant Pathology 38, 431-5.

Zadoks JC, Schein RD, 1979. Epidemiology and Plant Disease Management. New York, NY, USA: Oxford University Press.

\section{Supporting Information}

Additional Supporting Information may be found in the online version of this article at the publisher's web-site.

Figure S1. Frequency of studies with cultivars BMX Potência RR, M9144 RR or TMG803 at each significant covariates combination (baseline yield and yield response).

Table S1. Field studies specifications. 